\title{
PENGARUH HUMAN RELATION (HUBUNGAN ANTAR MANUSIA) DAN KONDISI \\ LINGKUNGAN KERJA TERHADAP KINERJA KARYAWAN
}

Oleh:

\author{
Rahmayuni Wulandari (17002108) \\ Email : rahmayuniwulandari19@gmail.com \\ Jurusan Administrasi Pendidikan
}

Fakultas Ilmu Pendidikan

\begin{abstract}
Abstrak
Human Relation (hubungan antar manusia) dalam perusahaan atau organisasi merupakan hal utama karena merupakan penghubung antara karyawan dengan sesama karyawan maupun karyawan dengan pimpinan. Kondisi lingkungan kerja juga merupakan faktor yang cukup penting dan sangat berpengaruh terhadap kinerja karyawan di suatu perusahaan. beberapa faktor yang mempengaruhi kondisi lingkungan kerja, antara lain: 1) Lingkungan kerja non fisik a) Faktor lingkungan sosial b) Faktor status sosial c) Faktor hubungan kerja dalam organisasi d) Faktor sistem informasi 2) Lingkungan kerja fisik a) Faktor lingkungan tata ruang kerja b) Faktor kebersihan dan kerapian ruang kerja. semakin tinggi kondisi fisik lingkungan kerja maka kinerja karyawan akan semakin meningkat, sebaliknya jika kondisi fisik lingkungan kerja rendah maka kinerja karyawan akan menurun juga. Lingkungan kerja yang baik mampu meningkatkan suasana yang nyaman dan semangat kerja pada karyawannya. Lingkungan kerja fisik yang baik tidak saja dapat menambah produktivitas tetapi juga dapat meningkatkan efisiensi kerja. Dampak yang lain yaitu pada kesungguhan pegawai dalam bekerja sehingga nantinya dapat meningkatkan kinerja mereka.
\end{abstract}

Kata kunci: Komunikasi, Kondisi Fisik Lingkungan Kerja, Kondisi Non Fisik Lingkungan Kerja, Kinerja Karyawan. 


\section{PENDAHULUAN}

Suatu perusahaan atau organisasi dapat tercapai tujuannya dikarenakan adanya aktifitas orang-orang yang menjadi karyawan atau anggotanya. Adanya human relation (hubungan antar manusia) dari orang-orang yang berada di dalam sebuah organisasi atau perusahaan, baik itu pada tingkat manajer maupun karyawan, nantinya kondisi lingkungan kerja tersebut dapat meningkatkan kinerja karyawan. Human Relation (hubungan antar manusia) adalah komunikasi antar pribadi yang manusiawi, yang berarti komunikasi telah memasuki tahap psikologis dimana komunikator dan komunikasinya saling memahami pikiran, perasaan dan melakukan tindakan secara bersama. Menurut pendapat Allo (1997:28), interaksi karyawan dalam lingkungan perusahaan atau instansi merupakan hal yang tidak dapat dipisahkan yang nantinya akan menimbulkan tingkat kepuasan kerja. Nurul (1995:67) juga menjelaskan bahwa situasi lingkungan perusahaan dalam melaksanakan tugas dan fungsinya antara karyawan yang satu dengan yang lain tidak terlepas dari interaksi demi kelancaran dan keharmonisan kerja. Human Relation (hubungan antar manusia) dalam perusahaan atau organisasi merupakan hal utama karena merupakan penghubung antara karyawan dengan sesama karyawan maupun karyawan dengan pimpinan. Kondisi lingkungan kerja juga merupakan faktor yang cukup penting dan sangat berpengaruh terhadap kinerja karyawan di suatu perusahaan. Kondisi lingkungan kerja yang baik, nyaman dan menyenangkan akan membuat karyawan merasa betah berada di ruangan kerjanya, lebih bersemangat dalam menyelesaikan pekerjaannya dengan baik meliputi kondisi lingkungan kerja fisik maupun kondisi lingkungan kerja non fisik. Nitisemito (2000:183) mengemukakan bahwa "Lingkungan kerja adalah segala sesuatu yang berada di sekitar para pekerja serta dapat mempengaruhi diri dalam menjalankan tugastugas yang dibebankan”. Karena kondisi lingkungan kerja merupakan salah satu faktor yang mempengaruhi pekerjaan, yang nantinya akan dihasilkan oleh karyawan selain human relation (hubungan antar manusia) dalam meningkatkan kinerja mereka. Kinerja adalah suatu hasil yang dicapai dalam pekerjaannya menurut kriteria tertentu yang berlaku untuk suatu pekerjaan (Robbins, 2001:156). Adanya kinerja yang tinggi, karyawan akan berusaha sebaik mungkin untuk mengatasi dan memecahkan masalah yang dihadapi dalam pelaksanaan tugas dan pekerjaanya. Sebaliknya adanya kinerja yang rendah, karyawan mudah menyerah terhadap keadaan bila mendapatkan kesulitan dalam 
melaksanakan tugas dan pekerjaannya sehingga sulit untuk mencapai tujuan yang diharapkan. Peningkatan kinerja tidak hanya didukung oleh keahlian dan pengetahuan, tetapi juga harus didukung oleh perilaku karyawan. Peningkatan kinerja karyawan merupakan hal yang penting untuk dilakukan oleh manajemen organisasi atau perusahaan demi tercapainya tujuan dalam menjaga kelangsungan hidup serta mempertahankan eksistensi organisasi atau perusahaan dalam persaingan yang ketat sekarang ini. Tujuan penelitian ini adalah untuk mengetahui seberapa besar pengaruh human relation (hubungan antar manusia) dan kondisi lingkungan kerja terhadap kinerja karyawan.

\section{TINJAUAN PUSTAKA}

Human Relation (Hubungan Antar Manusia) Human Relation (hubungan antar manusia) itu adalah pemimpin organisasi melakukan komunikasi dengan para karyawan secara manusiawi (human communication) untuk memotivasi mereka bekerjasama, sehingga hasilnya baik di samping mereka bekerja dengan hati senang (Onong, 1993:52). Menurut Davis (1989:152), "Hubungan Antar Manusia (Human Relation) adalah hubungan atau interaksi antara seseorang dengan orang lain baik dalam situasi kerja atau dalam organisasi”. Dalam kegiatan hubungan manusiawi ini ada cara yang bisa digunakan untuk membantu mereka yang sedang mengalami frustasi yakni dengan apa yang disebut konseling (counseling). Sebagai konselor (counselor) bisa dilakukan oleh pemimpin perusahaan, kepala humas, atau kepalakepala lainnya. Adanya konseling bertujuan untuk membantu konseling (counselee), yakni karyawan yang menghadapi masalah atau yang sedang mengalami frustasi, untuk memecahkan masalahnya atau mengusahakan terciptanya suasana yang menimbulkan keberanian untuk memecahkan masalahnya. Selain dengan konseling, ada beberapa cara dalam hubungan antar manusia antara lain: 1) Tindakan sosial 2) Kontak sosial 3) Komunikasi sosial Kunci human relation (hubungan antar manusia) adalah motivasi, agar karyawan bekerja dengan giat berdasarkan kebutuhan mereka, yakni kebutuhan akan upah yang cukup bagi keperluan hidup sehari-hari, kebahagiaan keluarga, kemajuan diri sendiri, dan lain sebagainya. Seseorang bergabung dalam suatu organisasi, karena dia berpikir organisasi tersebut dapat membantu dirinya untuk mencapai tujuannya. Semua tertuju pada sasaran yang direncanakan, dan di sini komunikasi memegang 
peranan yang penting. Komunikasi Komunikasi menurut beberapa ahli diantaranya adalah menurut Everett Rogers dalam Hafield Cangara (1998:20), Komunikasi didefinisikan sebagai "proses di mana suatu ide dialihkan dari sumber kepada satu penerima atau lebih, dengan maksud untuk merubah tingkah laku mereka”. Sedangkan menurut Arni Muhammad (2005:5) Komunikasi di definisikan sebagai "Pertukaran pesan verbal maupun non verbal antara si pengirim dengan si penerima pesan untuk mengubah tingkah laku". Komunikasi dapat diukur melalui beberapa indikator yaitu antara lain sebagai berikut: a) Kontribusi dalam penerapan komunikasi b) Dukungan rekan kerja c) Hubungan yang harmonis dengan rekan kerja d) Hubungan yang baik dengan pimpinan dalam kegiatan hubungan manusiawi ini ada cara yang bisa digunakan untuk membantu mereka yang sedang mengalami frustasi yakni dengan apa yang disebut konseling (counseling). Sebagai konselor (counselor) bisa dilakukan oleh pemimpin perusahaan, kepala humas, atau kepalakepala lainnya. Adanya konseling bertujuan untuk membantu konseling (counselee), yakni karyawan yang menghadapi masalah atau yang sedang mengalami frustasi, untuk memecahkan masalahnya atau mengusahakan terciptanya suasana yang menimbulkan keberanian untuk memecahkan masalahnya. Selain dengan konseling, ada beberapa cara dalam hubungan antar manusia antara lain: 1) Tindakan sosial 2) Kontak sosial 3) Komunikasi sosial Kunci human relation (hubungan antar manusia) adalah motivasi, agar karyawan bekerja dengan giat berdasarkan kebutuhan mereka, yakni kebutuhan akan upah yang cukup bagi keperluan hidup sehari-hari, kebahagiaan keluarga, kemajuan diri sendiri, dan lain sebagainya. Seseorang bergabung dalam suatu organisasi, karena dia berpikir organisasi tersebut dapat membantu dirinya untuk mencapai tujuannya. Semua tertuju pada sasaran yang direncanakan, dan di sini komunikasi memegang peranan yang penting. Komunikasi Komunikasi menurut beberapa ahli diantaranya adalah menurut Everett Rogers dalam Hafield Cangara (1998:20), Komunikasi didefinisikan sebagai "proses di mana suatu ide dialihkan dari sumber kepada satu penerima atau lebih, dengan maksud untuk merubah tingkah laku mereka". Sedangkan menurut Arni Muhammad (2005:5) Komunikasi di definisikan sebagai "Pertukaran pesan verbal maupun non verbal antara si pengirim dengan si penerima pesan untuk mengubah tingkah laku”. Komunikasi dapat diukur melalui beberapa indikator yaitu antara lain sebagai berikut: a) Kontribusi dalam penerapan komunikasi b) Dukungan rekan kerja c) Hubungan yang harmonis dengan rekan kerja d) Hubungan yang baik dengan pimpinan Lingkungan kerja non fisik menurut Ballback dan Slater (1999:27) adalah budaya organisasi yang menentukan perilaku 
orang di dalamnya, dimana budaya organisasi itu ditentukan oleh struktural formal organisasi serta norma dan nilai-nilai informal. Penyusunan organisasi yang kurang baik dapat menimbulkan kesimpang siuran tugas dan tanggung jawab masing-masing individu. Menurut Moekijat (2002:155-157), unsurunsur lingkungan kerja non fisik adalah sebagai berikut: 1) Kejelasan Tugas 2) Pengawasan Kerja Faktor yang Mempengaruhi Kondisi Lingkungan Kerja Menurut Subroto (2005:54), beberapa faktor yang mempengaruhi kondisi lingkungan kerja, antara lain: 1) Lingkungan kerja non fisik a) Faktor lingkungan sosial b) Faktor status sosial c) Faktor hubungan kerja dalam organisasi d) Faktor sistem informasi 2) Lingkungan kerja fisik a) Faktor lingkungan tata ruang kerja b) Faktor kebersihan dan kerapian ruang kerja. semakin tinggi kondisi fisik lingkungan kerja maka kinerja karyawan akan semakin meningkat, sebaliknya jika kondisi fisik lingkungan kerja rendah maka kinerja karyawan akan menurun juga. Lingkungan kerja yang baik mampu meningkatkan suasana yang nyaman dan semangat kerja pada karyawannya. Lingkungan kerja fisik yang baik tidak saja dapat menambah produktivitas tetapi juga dapat meningkatkan efisiensi kerja. Dampak yang lain yaitu pada kesungguhan pegawai dalam bekerja sehingga nantinya dapat meningkatkan kinerja mereka. Hal ini sesuai dengan pendapat Sarwoto (1991:91) yang mengatakan bahwa tata ruang kerja yang tepat, cahaya dalam ruangan yang cukup, suhu dan kelembaban udara yang baik, suara yang tidak mengganggu konsentrasi kerja dapat mempengaruhi dan meningkatkan efisiensi kerja para karyawan.

\section{KESIMPULAN}

Kondisi lingkungan kerja yang baik, nyaman dan menyenangkan akan membuat karyawan merasa betah berada di ruangan kerjanya, lebih bersemangat dalam menyelesaikan pekerjaannya dengan baik meliputi kondisi lingkungan kerja fisik maupun kondisi lingkungan kerja non fisik. Peningkatan kinerja tidak hanya didukung oleh keahlian dan pengetahuan, tetapi juga harus didukung oleh perilaku karyawan. Peningkatan kinerja karyawan merupakan hal yang penting untuk dilakukan oleh manajemen organisasi atau perusahaan demi tercapainya tujuan dalam menjaga kelangsungan hidup serta mempertahankan eksistensi organisasi atau perusahaan dalam persaingan yang ketat sekarang ini. 


\section{DAFTAR RUJUKAN}

Arikunto, Suharsimi (2010), Prosedur Penelitian Suatu Pendekatan Praktek, Cetakan Keempat Belas, Jakarta: PT. Rineka Cipta.

Arni, Muhammad (2005), Komunikas Organisasi, Jakarta: Bumi aksara. 